\title{
AILANTHUS ALTISSIMA (MILLER) SWINGLE - INVASIVE SPECIES IN THE FOREST HABITATS IN THE UPPER BASIN OF THE MOTRU RIVER
}

\author{
Nicolae Cătălin Dinucă ${ }^{1, *}$ \\ ${ }^{1}$ University of Craiova, Faculty of Agronomy, 19 Libertatii Street, Craiova, Romania
}

\begin{abstract}
Ailanthus altissima (Miller) Swingle is an invasive species found in forest habitats in Oltenia and beyond. The aggression and power of dissemination and development of this species is increasing. The thematic area provided in this paper is situated in the upper basin of the Motru river. Within this study had been aimed the identification and level of pressures and threats of the invasive species Ailanthus altissima in the forest habitats in the researched territory. These studies also noted the conservation status of the forest habitats in which this invasive species was encountered. In this area we identified this invasive species in the following forest habitats: 91E0* Alluvial forests with Alnus glutinosa and Fraxinus excelsior (Alno-Padion, Alnion incanae, Salicion albae), 91 V0 Dacian Beech forests (SymphytoFagion), 9130 Asperulo-Fagetum beech forests, 91M0 Pannonian-Balkanic turkey oak - sessile oak forests. This species influence the succesional dynamics and the floristic composition of the forest habitats, occupying increasingly more and more space.
\end{abstract}

Keywords: Ailanthus altissima, forest habitat, invasive species.

\section{INTRODUCTION}

Ailanthus altissima (tree of heaven), Simaroubaceae, is an early successional tree, native to China and North Vietnam, which has become invasive in Europe and on all other continents except Antarctica. It is most abundant in urban habitats and along transportation corridors, but can also invade natural habitats (Kowarik and Säumel, 2007).

All over the temperate to meridional zones, Ailanthus colonizes a broad array of urban habitats ranging from walls, fence rows, cracks of sidewalks, and road and railroad embankments to abandoned lots and urban parks (Hu, 1979; Kowarik, 1983; Kowarik and Böcker, 1984; Pan and Bassuk, 1986; Wei, 1989). The tree of heaven is an invasive species found in forest habitats in Oltenia and beyond. Ailanthus grows on a broad range of anthropogenic to natural sites, from stony and sterile soils to rich alluvial bottoms. In Europe, Ailanthus invades riparian forests as well as some mesic and xeric woodlands, preferentially in the submeridional to meridional zones (see below). The species can (co-)dominate pioneer forests on urban sites (Kowarik and Säumel, 2007). Currently, Romanian populations of Ailanthus altissima is not limited to urban and rural disruption they are also found in grass and forest habitats, affecting all natural capital. All habitats in which this species is found often have a low conservation value. The very high degree of vegetative regeneration of this species leads to an increase in the number of populations and their considerable 
development in terms of abundance and density. The aggression and power of dissemination and development of this species is increasing.

\section{MATERIALS AND METHODS}

\section{Study area:}

The thematic area provided in this paper is situated in the upper basin of the Motru river.

The upper basin of the Motru River comprises the southwestern slope of the Vâlcan Mountains, below the oslea peak, from where it originates, and the territory represented the crystalline shales and boundaries of the contact between the Vâlcan Mountains and the Mehedinti Mountains

The data was collected from May to September. 10 sample areas of 400-1000 $\mathrm{m}^{2}$ were chosen for each plant community within the habitats identified in the studied territory.

In each habitat, we have noted a floristic inventory, the abundence-dominance of each species, including the species Ailanthus and the anthropogenic impact that this species exerts on the physiognomy and floristic composition of each sample surface.

\section{RESULTS AND DISCUSSIONS}

Within this study had been aimed the identification and level of pressures and threats of the invasive species Ailanthus altissima (fig. 1) in the forest habitats in the researched territory. These studies also noted the conservation status of the forest habitats in which this invasive species was encountered.

In this area we identified this invasive species in the following forest habitats: 91E0* Alluvial forests with Alnus glutinosa and Fraxinus excelsior (Alno-Padion, Alnion incanae, Salicion albae), 91V0 Dacian Beech forests (SymphytoFagion), 9130 Asperulo-Fagetum beech forests, 91M0 Pannonian-Balkanic turkey oak - sessile oak forests.

This species influence the succesional dynamics and the floristic composition of the forest habitats, occupying increasingly more and more space. In terms of the abundance of individuals in a population, this varies depending on the type of habitat in which it is installed. Effective sexual reproduction and also to vegetative reproduction by vigorous root suckers growing from root budsand, clonal growth, are factors that cause a massive increase in the number of individuals in a population.

The first habitat to be noted in is 91E0*Alluvial forests with Alnus glutinosa and Fraxinus excelsior (Alno-Padion, Alnion incanae, Salicion albae) (CLAS. PAL.: 44.3, 44.2 şi 44.13; RO habitat type code: R4401, R4402, R4405, R4407, R4408). Within this priority habitat, the Salicetum albae Issler 1924 plant community has been identified and analyzed. In the floristic composition of phytocoenosis of this pant community are found with a high constancy the following species: Salix alba (3), S. fragilis (2), Populus nigra (+), Ulmus glabra (+), Angelica sylvestris (+-1), C. remota (1), C. sylvatica (+), Cirsium oleraceum (+), Equisetum telmateia (+-1), Filipendula ulmaria (+), Lycopus europaeus (+-1), Lysimachia nemorum (1-2), Rumex sanguineus (+-1), Stellaria nemorum (+-1), Urtica dioica (1). The tree of heaven has a high abundance-dominance (1-2) within the phytocoenoses analyzed within this plant community, especially near of rural habitats and in some places where household waste is stored. 10 sample areas were also identified and analysed from this habitat, which builds the plant community Stellario nemorumAlnetum glutinosae (Kästner 1938) Lohmeyer 1957. The results obtained have seen a large dominance of the tree of heaven only in rural and other anthropogenic factors. 


\begin{tabular}{l}
\hline \\
$\begin{array}{c}\text { Current Trends in Natural Sciences } \\
\text { Vol. 10, Issue 19, pp. 175-180, 2021 } \\
\text { https://doi.org/10.47068/ctns.2021.v10i19.023 }\end{array}$ \\
$\begin{array}{l}\text { Current Trends in Natural Sciences (CD-Rom) } \\
\text { ISSN: 2284-9521 } \\
\text { ISSN: 228n-953X } \\
\text { ISSN-L: 2284-9521 } \\
\text { ISSN-L: 2284-9521 }\end{array}$ \\
\hline
\end{tabular}

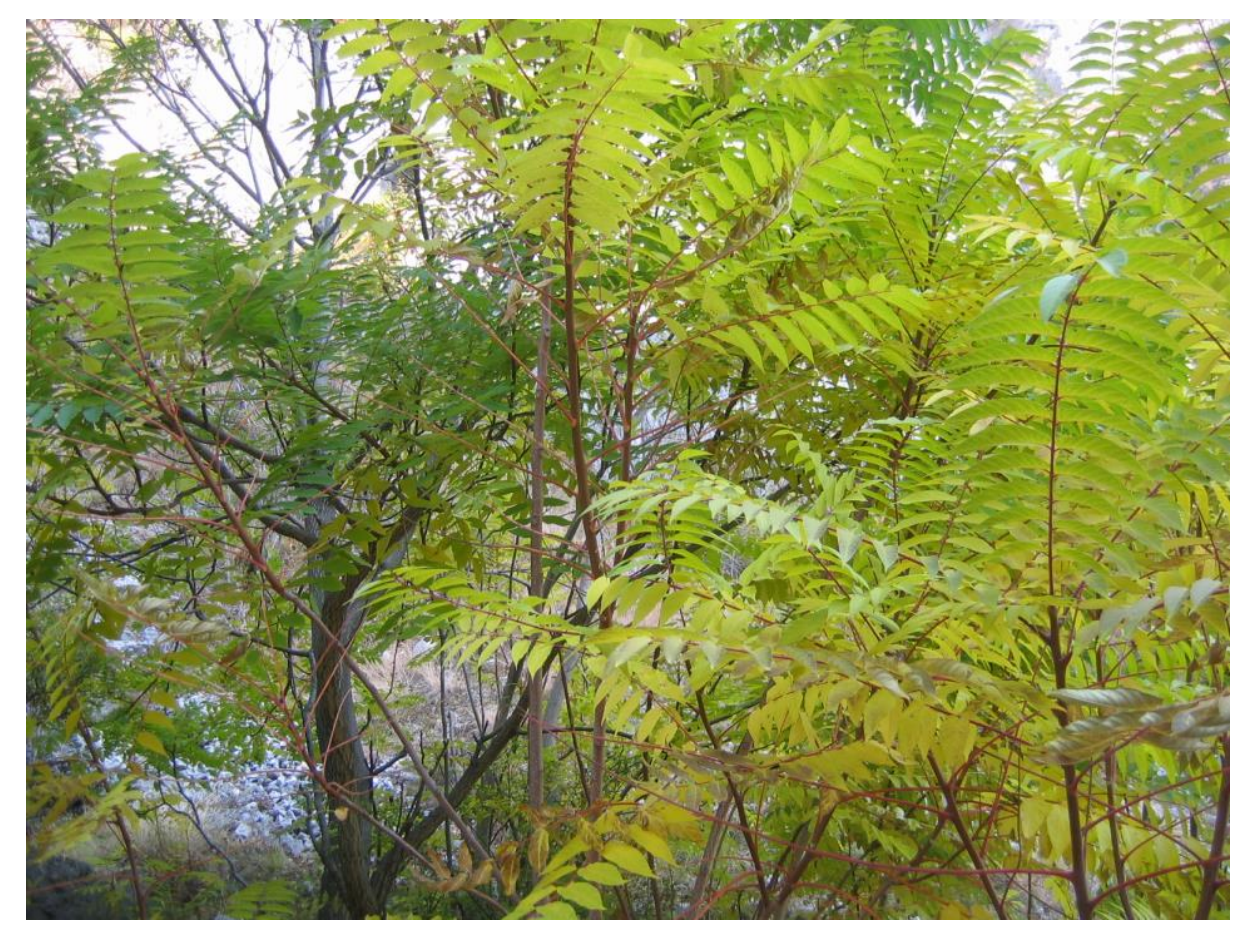

Figure 1. Ailanthus altissima in the upper basin of the Motru river

The second type of forest habitat analysed in the researched territory is: 91V0 Dacian Beech forests (SymphytoFagion) (CLAS. PAL.: 41.1D2; RO habitat type code: R4101, R4103, R4104, R4108, R4109, R4116. From this habitat was identified Pulmonario rubrae-Fagetum (Soó 1964) Täuber 1987 plant community, thus 10 sample surfaces were analyzed in terms of physiognomy and floristic composition, as well as the negative impact exerted by Ailanthus altissima. In this case it was found that the tree of heaven was not identified in all sample surfaces, meeting only in 4 sample surfaces and the abundance-dominance of this invasive species being much smaller (+-1). Such phytocoenoses were analysed in the MareValley and Brebina.

In the upper basin of Motru, another important habitat is 9130 Asperulo-Fagetum beech forests (CLAS. PAL.: 41.13; RO habitat type code: R4118, R4119, R4120). It is edified by the plant community Carpino-Fagetum Paucă 1941.

In 7 of the 10 sample areas analysed within this habitat, the tree of heaven was identified.

In the floristic composition of phytocoenosis of this pant community are found with a high constancy the following species: Fagus sylvatica (4), Carpinus betuluus (2), Anemone nemorosa (1), Lamiastrum (Lamium) galeobdolon (+), Galium odoratum (+-1), G. schultesii (+-1), Melica uniflora(+), Dentaria glanfdulosa (1), Aposeris foetida (+), Helleborus odorus (+), Scilla bifolia (+1), Isopyrum thalictroides (+-1), Corydalis cava (+). Along with Ailantus altissima, an indersirable species that develops within the phytocenosis of this habitat and which has a negative effect on the grassy layer and under the shrub is Rubus hirtus.

The tree of heaven has a high abundance-dominance (+-1) within the phytocoenoses analyzed within this plant community, also near of rural habitats and in places with a high degree of anthropization, or example on the MareValley and the Pesteana Valley. 
Another analyzed habitat in the upper basin of Motrul is 91M0 Pannonian-Balkanic turkey oak sessile oak forests (CLAS. PAL.: 41.76; RO habitat type code: R4132, R4133, R4140, R41494155).

This habitat is spread over very small areas in certain plots in the area and and is edified by the plant community - Quercetum petraeae-cerris Soó (1957) 1969. Most of the time Q. cerris is missing. Q. frainetto appears in some phytocoenoses. Also, it is of particular importance from the point of view of biodiversity. Analysis of the 10 sample areas found that in some phytocoenoses the abundance-dominance of the tree of heaven is relatively small in the northern part of the territory surveyed and higher in the southern part, with the proximity of rural, anthropized habitats. This ranges from + to 1. In the shrub layer are commonly found: Sorbus torminalis, Ligustrum vulgare, Euonymus europaeus, Crataegus monogyna, Viburnum lantana and Cornus sanguinea. De multe ori acest strat arbustiv este disturbat de dezvoltarea of the tree of heaven. In the floristic composition of the grass layer participates with a high constancy the following species: Festuca heterophylla, Carex montana, Poa nemoralis, Potentilla micrantha, Tanacetum corymbosum, Campanula persicifolia, Viscaria vulgaris, Lychnis coronaria, Campanula persicifolia, Vincetoxicum hirundinaria, Melica uniflora, Silene nutans, Hieracium sabaudum, Galium schultesii, Lathyrus vernus, Helleborus odorus, Asperula taurina, Brachypodium sylvaticum, Poa nemoralis, Carex praecox, Astragalus glycyphyllos, Lithospermum purpureo-coeruleum, Teucrium chamaedrys.

The very high degree of vegetative regeneration of this species leads to an increase in the number of populations and their considerable development in terms of abundance and density.

Research has shown that within the forest habitats of the month this species develops very well alongside another invasive species Amorpha fruticosa.

In other habitats it meets together with other invasive woody species: Robinia pseudoacacia and Acer negundo. In the upper basin of Motru river, among the invasive grass species that grow alongside Ailanthus we can mention: Impatiens glandulifera, Ambrosia artemisiifolia, Erigeron canadensis, E. annuus, Oxalis stricta, Reynoutria japonica, Phytolacca americana.

Ailanthus altissima is a particularly adaptable species with a great spreading power. Ecological factors, especially the substrate on which species develop greatly influences the development of individuals in the population. Ailanthus altissima is adaptable to a very wide range of soil conditions and $\mathrm{pH}$ values and we found it within a wide range of climatic conditions. Species installs very quickly, is very lively and has a very high growth rate. (Niculescu et al., 2018).

In areas subject to high levels of pollution, Ailanthus altissimais among the most tolerant tree species (Kovacs et al., 1982). It is highly resistant to SO2 (Ranft and Dässler,1970) and other main components of air pollution.

The studies carried out found that the threats and pressures of Ailanthus altissima on biodiversity in forest habitats are due to interspecific competition, allelopathic property of this species and very high drajonation capacity and thus the large number of drajons in phytocoenosis. Thus, the very high density of drajons has a very high negative impact on the composition and floristic physiognomy within each phytocoenoses that build the plant communities corresponding to each habitat analysed in the territory under study. 


\section{CONCLUSIONS}

Deliberate or accidental introduction of tree of heaven in the forest habitats is considered as one of the major sources of change of the physiognomy of the phytocoenoses. This species influence the succesional dynamics and the floristic composition of the forest plant communities, occupying increasingly more and more space (Niculescu et al., 2018).

The studies carried out found that the threats and pressures of Ailantus altissima on biodiversity in forest habitats are due to interspecific competition, allelopathic property of this species and very high drajonation capacity and thus the large number of drajons in phytocenosis.

Thus, the very high density of drajons has a very high negative impact on the composition and floristic physiognomy within each phytocenoses that build the plant communities corresponding to each habitat analysed in the territory under study.

\section{REFERENCES}

Coldea, Gh. (1997). Les associations vegetales de Roumanie [Romanian plant associations], Ed. Presses Universitaires de Cluj, Cluj- Napoca

Gafta, D., Mountford, O., (coord.). (2008). Manual de interpretare a habitatelor Natura 2000 din România [Interpretation manual of Natura 2000 habitats in Romania], Ed. Risoprint, Cluj-Napoca

Géhu, J.-M., Rivas-Martinez, S. (1981). Notions fondamentales de Phytosociologie [Fundamentals of Phytosociology,]Ber. Intern. Symposion Syntaxonomie in Rinteln: 1-33.

Hu, S.Y. (1979). Ailanthus, Arnoldia 39, 29-50.

Imbrea, I. M., Nicolin, A. L., Niculescu, M. (2008). Studies concerning the rock vegetation in the Cheile Globului Nature Reserve (South-Western Romania), Bulletin of University of Agricultural Sciences and Veterinary Medicine, Cluj-Napoca, Vol. 65 (1), ISSN 1843-5246, AcademicPress, Cluj-Napoca, p.141146,http://journsals.usamvcj.ro/agriculture/ index, http://www.cabi.org/AbstractDatabase

Kovacs, M., Opauszky, I., Klincsek, P.K., Podani, J. (1982). The leaves of city trees as accumulation indicators. In: Steubing, L.S., Ja“ger, H.J. (Eds.), Monitoring of Air Pollutants by Plants. Methods and Problems Dr. W. Junk, The Hague, pp. 149-153.

Kowarik, I., (1983). Zur Einbu“rgerung und zum pflanzengeographischen Verhalten des Go“tterbaumes (Ailanthus altissima (Mill.) Swingle) im franzo“sischen Mittelmeergebiet (Bas-Languedoc) [Naturalization and plantgeographical behavior of the god tree (Ailanthus altissima (Mill.) Swingle) in the French Mediterranean region (Bas-Languedoc)]. Phytocoenologia, 11, 389-405.

Kowarik, I., Böcker, R. (1984). Zur Verbreitung, Vergesellschaftung und Einbu“rgerung des Go“tterbaumes (Ailanthus altissima (Mill.) Swingle) in Mitteleuropa [Distribution, socialization and naturalization of the god tree (Ailanthus altissima (Mill.) Swingle) in Central Europe]. Tuexenia 4, 9-29

Kowarik, I., Säumel, I. (2007), Biological flora of Central Europe: Ailanthus altissima (Mill.) Swingle, Perspectives in Plant Ecology, Evolution and Systematics 8 (2007) 207-237, https://doi.org/10.1016/j.ppees.2007.03.002

Mucina, L., (1997). Conspectus of Classes of European vegetation, Folia Geobot. Phytotax., Praha, 32: 117-172.

Nicolin, A. L., Niculescu, M., Imbrea, I. M., Arsene, G. G., Bădescu, B., Bărbos, M. I., Filipaș L. (2014). Biodiversity, spatial and conservation status assessment on alluvial gallery-forests within the Natura 2000 site, Research Journal of Agricultural Science, Vol. 46 (2), 222-232 p., Timisoara

Niculescu, M., Bercea, I., Matei, G., Nuta, I.S., Iovu, I., Ciupitu, S. A., Salceanu, C. (2009). Researches about Quercus cerris forests situated in the North-East of Dolj County, Analele Universitatii din Craiova, Agricultura, Montanologiel Annals of the University of Craiova, Agriculture, Montanology, Cadastre series, http://agronomie.administrativ.ucv.ro/aamc/index.php/aamc, vol. XXXIX/B

Niculescu Mariana (2016). Diversity, distribution and ecology of the freshwater natural habitats from Southern of Oltenia, Romania- USAMV Bucuresti, SCIENTIFIC PAPERS-SERIES A-AGRONOMY, Volume: 59, 2016,

http://agronomyjournal.usamv.ro/index.php/scientific-papers/past-issues?id=602

Niculescu, M., Olaru, L.A., Cojoacă, F. D. (2018). Study of phytosociology and ecology of Ailanthus altissima (Miller) Swingle - invasive species in the South-Western of Romania, Analele Universităţii din Craiova, seria Agricultură - Montanologie - Cadastru (Annals of the University of Craiova - Agriculture, Montanology, Cadastre Series), Vol: XLVIII:276-281, http://anale.agro-craiova.ro/index.php/aamc/article/view/1008 


\section{Current Trends in Natural Sciences}

Vol. 10, Issue 19, pp. 175-180, 2021

https://doi.org/10.47068/ctns.2021.v10i19.023

Current Trends in Natural Sciences (on-line)

ISSN: 2284-953X

Current Trends in Natural Sciences (CD-Rom)

ISSN: 2284-9521

ISSN-L: 2284-9521

ISSN-L: 2284-9521

Pan, E., Bassuk, N. (1986). Establishment and distribution of Ailanthus altissima in the urban environment. J. Environ. Hortic. 41, 1-4.

Ranft, H., Da“ssler, H.G. (1970). Smoke-hardiness test carried out on woods in a SO2-chamber. Flora 159, $573-588$.

Rodwell J.S. et al. (2002). The Diversity of European Vegetation, Raport EC-LNV nr. 2002/054, Wangeningen

Sanda, V., Popescu, A., Barabaş, N. (1997). Cenotaxonomia şi caracterizarea grupărilor vegetale din România [Cenotaxonomy and characterization of plant groups in Romania], St. Com., Muz. Şt. Nat. Bacău, 14: 5-366

Trif, CR., Făgăraș, MM., Hîrjeu, NC., Niculescu, M. (2015). Ghid sintetic de monitorizare pentru habitate de interes comunitar (sărături, dune continentale, pajiști, apa dulce) din Romania [Synthetic monitoring guide for habitats of community interest (salts, continental dunes, meadows, fresh water) in Romania], Editura Boldaş, Constanta, $134 \mathrm{p}$.

Tutin, T.G., (eds.), (1964-1980 \& 1993). Flora Europaea. Vols 1-5 \& Vol. 1 (2nd edition), Cambridge University Press.

Weber, H.E., Moravec, J., Theurillat, P. (2000). International Code of Phytosociological Nomenclature. 3rd edition, Journal of Vegetation Science, 11 (5): 739-768.

Wei, J., (1989). Study on the spontaneous trees in Beijing urban ecosystems. In: Rusong, W. (Ed.), Human Ecology in China. China Science and Technology Press, Beijing, pp. 79-82. 